\title{
Education of Road Safety Awareness to Secondary School Students in Phu Yen Province, Vietnam Based on the Community
}

\author{
Nguyen Trung Luong ${ }^{1}$, Do Thi Thao ${ }^{2, *}$, Dang Loc Tho ${ }^{3}$ \\ ${ }^{1}$ Faculty of Psychology and Education, Hanoi National University of Education, Hanoi, Vietnam \\ ${ }^{2}$ Faculty of Special Education, Hanoi National University of Education, Hanoi, Vietnam \\ ${ }^{3}$ National College for Education, Hanoi, Vietnam \\ *Corresponding author: thaodt@hnue.edu.vn
}

Received May 14, 2018; Revised June 25, 2018; Accepted June 27, 2018

\begin{abstract}
This article aims to help people in traffic to implement good road traffic safety law, cultural behavior when participating in traffic and bring safety and happiness for themselves and their families. This article aims to assess the current status of community-based road safety law education for secondary school students in Tuy Hoa City, Phu Yen Province, Vietnam. Research results show that the community-based awareness-raising activities on road traffic safety for students have been implemented, but there have not been many new, innovative and effective activities. Therefore, there is a need for breakthrough measures, with the linkage between families, schools and communities such as: (1) raising resources to ensure the education of the sense of compliance with road traffic law among secondary school students in Tuy Hoa City, Phu Yen Province based on the community; (2) developing a traffic safety propaganda campaign in association with the organization of the 'Youth Festival and Culture of Transportation' and organizing contests on the road traffic safety law; (3) promoting volunteerism and youth activities to ensure traffic order and safety, replicating models, works and jobs of students participating in ensuring traffic order and safety, and educating union members who violate traffic safety.
\end{abstract}

Keywords: road traffic safety, legal education, youth union, community

Cite This Article: Nguyen Trung Luong, Do Thi Thao, and Dang Loc Tho, "Education of Road Safety Awareness to Secondary School Students in Phu Yen Province, Vietnam Based on the Community.” American Journal of Educational Research, vol. 6, no. 7 (2018): 893-901. doi: 10.12691/education-6-7-2.

\section{Introduction}

At present, traffic safety is one of the top issues in the world and the whole society. On the roads, there have been many posters and signs fixed at corners of the road with vivid visual images combined with the slogan of "Traffic safety is the happiness of every home", "One Minute - Lifetime Happiness"... for the purpose of helping traffic participants implement the Road Traffic Safety Law, adapting to the traffic, bringing safety and happiness to themselves and their families, which contributes to the building of a civilized society.

Decade of action for traffic safety from 2011 to 2020 was approved by the United Nations General Assembly in March 2010. This is a reaction to concerns about global deaths caused by the Organization World Health Organization (WHO). "The data collected by WHO shows that about 1.3 million people die each year from traffic crashes, 50 million injuries and disabilities each year, and $90 \%$ of road accident victims in the developing countries [1]. Mobile phone use and messaging are contributing to traffic accidents [1]. The authors Alicea, L et al. (2010), B
Colucci et al. (2012), Colucci, B et al. (2013) studied and used the Puerto Rico Public Library database "From the beginning of this millennium, the average number of accidents was 285,000 per year, of which 4,764 reported deaths during the decade, of which 1,472 were pedestrians, accounting for $31 \%$ of the total dead" [2,3,4]. International experts believe that "traffic accidents can be prevented if a global action plan, including specific performance measurements, can save millions of lives. An important component of reducing traffic congestion is the creation of strategic alliances and alliances between the private sector, the public sector and academia [1]. Tamara Hoekstra et al. (2011) also described the advantages and disadvantages of some popular campaigns and introduced some new methods that demonstrate the purpose of road safety campaigns [5]. "Early education for the next generation of drivers and road users plays a leading role in raising awareness and reducing road deaths," said Ainsworth, Highway Safety-Human Factors (2010) public highways. Citizens' awareness of public policy, laws and regulations, combined with effective and timely training, safety and cooperation, are important factors that can help reduce road deaths" [6]. "Road traffic today is inherently dangerous. In fact, in contrast to other modes of transport 
(such as rail and air), the road system has not been designed to ensure the best safety" [7]. "It's important to inform the public about traffic rules, raise awareness or guide people to avoid dangerous behaviors and take alternative safeguards" [8].

According to the report of the Government of Vietnam on road traffic safety, in 2017 there were 19,807 accidents. 8,034 people died, and 16,913 people were injured. Regarding the causes of traffic accidents, $24.05 \%$ of accidents caused by drivers violating lanes, road sections; 9.55\% due to vehicle speed violation; $9.37 \%$ due to not paying attention; $6.47 \%$ due to not giving way; $6.26 \%$ due to overtaking; $6.13 \%$ due to a violation of driving procedures; $2.17 \%$ due to avoiding cars; $2.04 \%$ due to alcohol use; $33.96 \%$ due to violation of road signboards, mis-stopping, driving without driver's licenses, lack of technical safety, due to pedestrians, traffic works and other causes" [9]. Traffic accidents in general, the violation of the Road Traffic Law in adolescence in particular are becoming a painful problem - the concern of the whole society. A number of traffic accidents involving young people have been reported to be statistically significant [10]. The proportion of upper secondary school students is related to $90 \%$ of the total number of child traffic accidents and the number of deaths attributed to traffic accidents in this group tends to increase in the last two years [11]. In Phu Yen province, according to statistics of Phu Yen Traffic Safety Board, in 2017 "there were 454 accidents in the province, killing 151 people and injuring 546 people. Traffic accidents occur most in teenagers, most of them are students of high schools, colleges and universities in Phu Yen province" [12].

In Vietnam, there are many researches to develop models and solutions to enhance the effectiveness of communication activities and raise the awareness of the law on traffic safety for youth. Typically, there are authors such as Nguyen Nhu Chien [13], Ngo Xuan Thang [14], Tran Son Ha [15]. Basically, the works have stated many scientific values but only mentioned the common features, wide area. To propagate and educate the awareness on road traffic safety, to form a "culture of traffic" for students of secondary schools in our country in general and Tuy Hoa city, Phu Yen province in particular, we announce the results of research and propose measures to educate the road traffic safety awareness of secondary school students in Tuy Hoa city, Phu Yen province based on the community.

\section{Content}

\subsection{Community-based Education of Road Traffic Safety Awareness to Secondary School Students}

* The goal of the road safety education awareness to youth union members: The goal of traffic safety education for students in general and secondary school students in particular is to achieve the basic knowledge in order to prevent and avoid accidents, and develop the sense of law observance when participating in traffic. Youth union members are leading students, leading in all activities and movements of the school. Strengthening the propaganda to improve the sense of compliance with the Law on Road Traffic, compliance with the rules of traffic safety for youth union members of secondary school students will create many good examples for other students. Thereby, the effect will spread to the majority of students in the whole school, raising awareness of the law enforcement on road traffic safety.

* The content of education of road safety awareness to union members: road traffic safety awareness among secondary school students, how to participate in road traffic safety among secondary school students, understanding of traffic safety law, organizing volunteering activities to get youth union leading members participate in ensuring traffic safety, promoting and scaling up works and models to ensure traffic safety among youth union members.

* The process of educating road safety awareness to the union members: The process consists of three stages as follows:

\begin{tabular}{|l|l|l|}
\hline \multicolumn{1}{|c|}{$\begin{array}{l}\text { Stage 1: } \\
\text { Conducting } \\
\text { comprehensive } \\
\text { and systematic } \\
\text { education on } \\
\text { traffic safety in } \\
\text { the school. }\end{array}$} & $\begin{array}{l}\begin{array}{l}\text { Stage } 2: \\
\text { Developing a } \\
\text { regulations } \\
\text { for traffic } \\
\text { with clear } \\
\text { criteria } \\
\text { attached to } \\
\text { the annual } \\
\text { evaluation } \\
\text { criteria. }\end{array} \\
\text { functional } \\
\text { agencies and } \\
\text { schools to promote } \\
\text { the dissemination } \\
\text { and renewal of law } \\
\text { dissemination and } \\
\text { education for } \\
\text { union members } \\
\text { and youths } \\
\text { participating in } \\
\text { traffic. }\end{array}$ \\
\hline
\end{tabular}

Stage 1: Being persist in education of traffic safety law in order to have a generation of citizens who have a habit of respecting the law in general and the Law on Road Traffic in particular. We need to focus on teenagers, especially secondary school students. Consequently, extensive and systematic education and training on traffic safety education should be carried out right from the school. We need to help the teenagers build the habit of self-compliance with the Road Traffic Law. Accordingly, the propaganda to build the traffic culture should include specific action programs, new content, diversity of forms of activities in order to attract large participation.

Stage 2: Youth unions should develop a code of conduct on traffic with clear criteria attached to the annual evaluation criteria. In parallel, the promotion of meaning and awareness in the implementation of traffic law should further enhance the awareness of parents to set an example and pay more attention to the education of legal consciousness of traffic law and safety for their children.

Phase 3: The Traffic Police should strengthen the patrol and control, focus on reminding and resolutely handling cases of juvenile delinquency, especially cases of recidivism; at the same time, coordinate with schools in promoting the dissemination and renewal of the law dissemination and education contents to the students.

In addition, Traffic Safety Law needs to be taught intensively to become a universal subject in the school teaching program system.

* Characteristics of community based education of road safety awareness to union members 
The community, in the scope of this research, focuses on exploitation of the learning environment and the training of law consciousness in general and the sense of traffic safety law in particular.

"Law Enforcement" can be understood as moral values, sense of observance of rules and discipline in the school and formed during the cognitive process (learning) from which to have the right understanding of the law, respect and self-discipline as required by law. Regarding the training of law consciousness in the school, at the elementary level, students will learn the "Ethics"; Upper secondary students will learn "civics education" and have some extra activities.

Community-based education of road safety awareness to students is concerned due to the safety of people. In the recent years, in order to find modern teaching methods, to drastically reduce hours of study, to create excitement during school hours, many schools have coordinated with many traffic police units in the area to conduct educational activities such as traffic safety seminars under the flag, writing contests of "students with cultural transportation", stage performances ...

* Measures to educate road safety awareness to union members based on community

To some extent, education of road safety awareness include the propagation of traffic safety laws for people to raise their awareness of respect for law and strictly comply with the law.

In broader extent, education on traffic safety is a common practice, field, and rank (in the usual sense, not in the sense in the law on public employees). Education on traffic safety law includes all stages to serve the work of dissemination and education of traffic safety law: orientations for legal dissemination and education; To elaborate programs and plans on dissemination and education of law, draw experiences, scientific research, raise theoretical qualifications on traffic safety education.

It can be understood that "Traffic safety awareness measures are activities that are purposeful, organized, planned, methodically and formally defined in terms of the content that has been identified. Those who receive legal education to form and develop in them the knowledge system of opinion, thought and psychology; attitudes and sentiments towards the law and order; the assessment of the fairness and correctness of the current law, the lawful acts of citizens, the state and organizations in society."

Schools need to provide traffic safety education for teachers to play a very important role in the effectiveness of teaching at the school. The teachers provide traffic safety education for the students. Teachers need to be role models in the enforcement of traffic safety regulations for students to follow, strictly follow the traffic safety teaching plan as prescribed; at the same time, implement the propaganda weekly. The organizers should invite traffic safety experts to talk to students on relevant issues.

Family is the first and most important school for students to participate in traffic. Many of the knowledge can be learned from parents, so children need educating the sense of following the traffic law from young age. "Education of children in the traffic carefully and meticulously every minute not only related to their lives and property but also related to many others. The knowledge of traffic "eaten in the blood" from family communication during the first years of life is extremely necessary.

\subsection{The Status of Road Traffic Safety Awareness among the Union Members of Upper Secondary Schools in Tuy Hoa City, Phu Yen province, Vietnam Based on the Community}

\subsubsection{Organizing the Survey}

* Purpose of the survey: Assessment of traffic situation of members of upper secondary schools in Tuy Hoa City, Phu Yen Province, as a basis for proposing measures to educate the law consciousness. Road traffic safety for union members based on community to prevent violations.

* Content of the survey: Survey on the behavior of traffic participants of members of upper secondary schools and current situation of measures to educate road traffic safety awareness for union members of high schools in Tuy Hoa city.

* Survey method:

- Method of investigation: Purpose: To gather information from teachers and union members about the sense of law when participating in road traffic safety; Investigators: 33 officers in charge of the delegation at the high schools, the provincial Youth Union, the district delegation, the Phu Yen wards / communes and the principals of 7 senior secondary schools in Tuy Hoa City, Phu Yen Province. 1,000 members at 07 high schools in Tuy Hoa City, Phu Yen Province; Survey instrument: Feedback form.

- Interviewing method: Purpose: Collect more information on the research problem; Interviewees: teachers and members at 07 schools in Tuy Hoa city, Phu Yen province.

- Method of data processing in mathematical statistics: Purpose: Processing of research results have been collected; Content: To sum up the answers of lecturers and union members, to apply the hierarchical assessment and correlation coefficient tests to process the collected data.

* Location and survey: High schools in Tuy Hoa; Teachers and students at high schools in Tuy Hoa.

\subsubsection{Survey Results Status}

* Actual state of road traffic safety law of members of high schools in Tuy Hoa City:

To learn more about the traffic safety awareness of union members of Tuy Hoa City High School, Phu Yen Province, the author conducted a survey of over 1.000 union members on awareness and understanding of law of road traffic safety, the results are presented in Table 1.

From Table 1, most of the members of the high school surveyed are well aware of the traffic safety law through various forms, as follows: Extra-curricular activities on traffic safety organized by the Youth Union ranked first with $\mathrm{M}=1.21$ followed by the youth radio program organized by the Youth Union, with $\mathrm{M}=1.23$. Parents and friends perceptions were the lowest in the survey with $69.2 \%, M=1.38$. 
Table 1. The ability to recognize some road traffic safety laws of union members in Tuy Hoa City, Phu Yen Province

\begin{tabular}{|c|c|c|c|c|c|c|}
\hline \multirow[b]{2}{*}{ No } & \multirow[b]{2}{*}{ Content } & \multicolumn{3}{|c|}{ Description } & \multirow[b]{2}{*}{$\mathbf{M}$} & \multirow[b]{2}{*}{ Rank } \\
\hline & & $\begin{array}{c}\text { Clear } \\
\text { understanding }\end{array}$ & $\begin{array}{l}\text { Being aware of, } \\
\text { not understanding }\end{array}$ & $\begin{array}{l}\text { Not heard } \\
\text { of }\end{array}$ & & \\
\hline 1 & $\begin{array}{l}\text { Receiving information through the activities held by school Youth } \\
\text { Union }\end{array}$ & 84.2 & 10.5 & 5.3 & 1.21 & 1 \\
\hline 2 & $\begin{array}{l}\text { Receiving information through the radio channel held by school } \\
\text { Youth Union }\end{array}$ & 82.5 & 11.8 & 5.7 & 1.23 & 2 \\
\hline 3 & $\begin{array}{l}\text { Receiving information through the contests of Road safety held by } \\
\text { school Youth Union }\end{array}$ & 78.3 & 15 & 6.7 & 1.28 & 3 \\
\hline 4 & Receiving information through the family, teachers and friends & 69.2 & 22.7 & 8.1 & 1.38 & 4 \\
\hline
\end{tabular}

As a result, the youth union members at the schools conducting the survey have a certain knowledge of the road traffic safety law through various means and means of communication. This shows that the cadres of Tuy Hoa City Secondary School in Phu Yen Province have done a good job of propagandizing to equip the members.

* The actual situation

Through Chart 1 , the members regularly participate in traffic, hammering hammock (85\%), ride in multiple rows (77\%); Sometimes they go in the wrong lane (53\%) and pass the red light (37\%). Thus, the awareness of traffic participation of members of upper secondary schools is still not high despite knowing and understanding of traffic safety law but many union members still do not perform well, this is very dangerous for themselves and to other road users.

* The effect of recognizing traffic safety law for union members of Tuy Hoa city, Phu Yen province

The recognition of the Road Safety Law has helped the members to be more responsible and self-aware when participating in traffic, which is clearly shown in Table 2.

In general, both teachers and union members understand the importance of traffic safety laws, which help protect their life when participating in road traffic (88.7\%), and understand the basic law when participating in road traffic (76.6\%). Thus, being aware of the law is extremely important and essential for every person, especially school students.

* Current situation of using traffic safety awareness measures for members of high schools in Tuy Hoa City, Phu Yen Province

Chart 2 shows that measure 1, "Propagating the propaganda organization", both the level of utilization and the level of effectiveness are high (91.8 - 92.5\%). Measures 3 and 6 have high levels of utilization but the effect is rather low. Measures less used as measures 2 and 5 , but the re-use efficiency is quite high. Specifically, measure 4 "Organize training courses on traffic safety knowledge" was not used by the users as well as highly appreciated the effectiveness of this measure.

Thus, the above numbers have said the education and propaganda of traffic safety awareness for the members of Tuy Hoa city's high schools in Phu Yen province has initially had basic effects, However, these tasks are still single and not really radical.

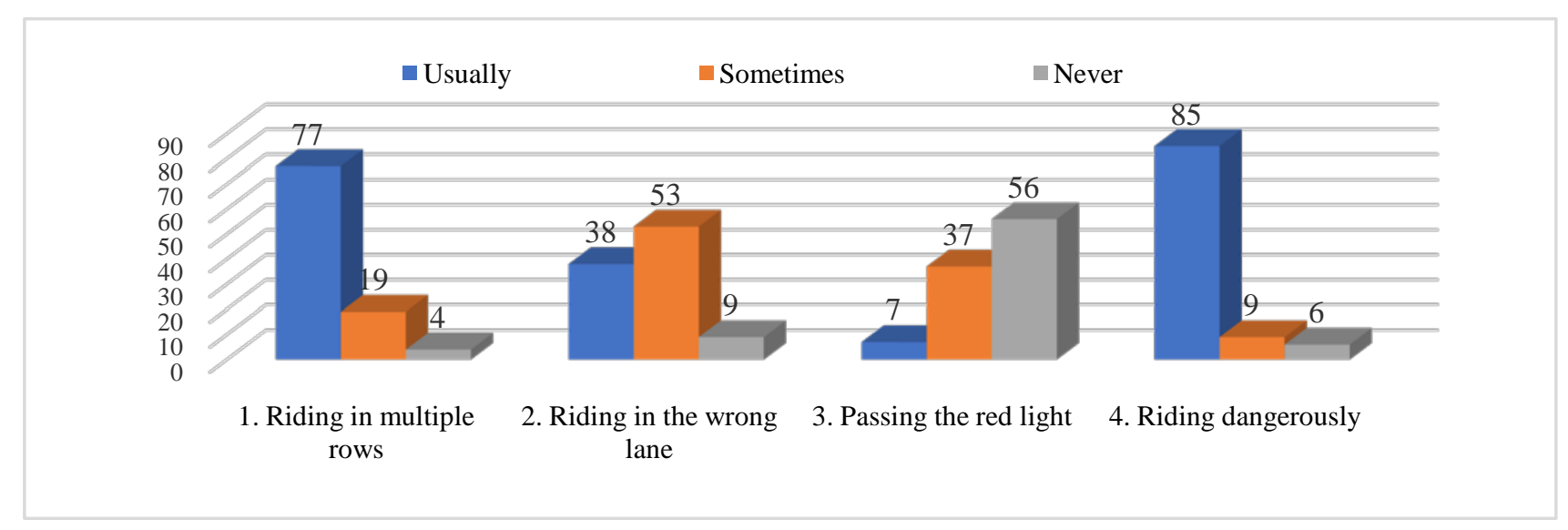

Chart 1. Traffic awareness and compliance with the Traffic Safety Law of youth union member of Tuy Hoa Secondary Schools

Table 2. Effect of traffic safety awareness for union members

\begin{tabular}{|c|c|c|c|c|c|c|c|c|c|}
\hline \multirow{3}{*}{ Effects } & \multicolumn{9}{|c|}{ Description } \\
\hline & \multicolumn{3}{|c|}{$\begin{array}{c}\text { Teachers } \\
(N=33)\end{array}$} & \multicolumn{3}{|c|}{$\begin{array}{l}\text { Union members } \\
\qquad(N=1000)\end{array}$} & \multicolumn{3}{|c|}{$\begin{array}{c}\text { Total } \\
(N=1033)\end{array}$} \\
\hline & Vol & Ratio & Rank & Vol & Ratio & Rank & Vol & Ratio & Rank \\
\hline $\begin{array}{l}\text { 1. Understanding the basic rules when } \\
\text { participating in road traffic }\end{array}$ & 29 & 87.9 & 1 & 762 & 76.2 & 2 & 791 & 76.6 & 2 \\
\hline $\begin{array}{l}\text { 2. Knowing to honor the life and self- } \\
\text { protect when participating in traffic }\end{array}$ & 21 & 63.6 & 3 & 895 & 89.5 & 1 & 916 & 88.7 & 1 \\
\hline $\begin{array}{l}\text { 3. Having a sense of participation and } \\
\text { complying with traffic safety laws }\end{array}$ & 26 & 78.8 & 2 & 528 & 52.8 & 3 & 554 & 53.6 & 3 \\
\hline
\end{tabular}




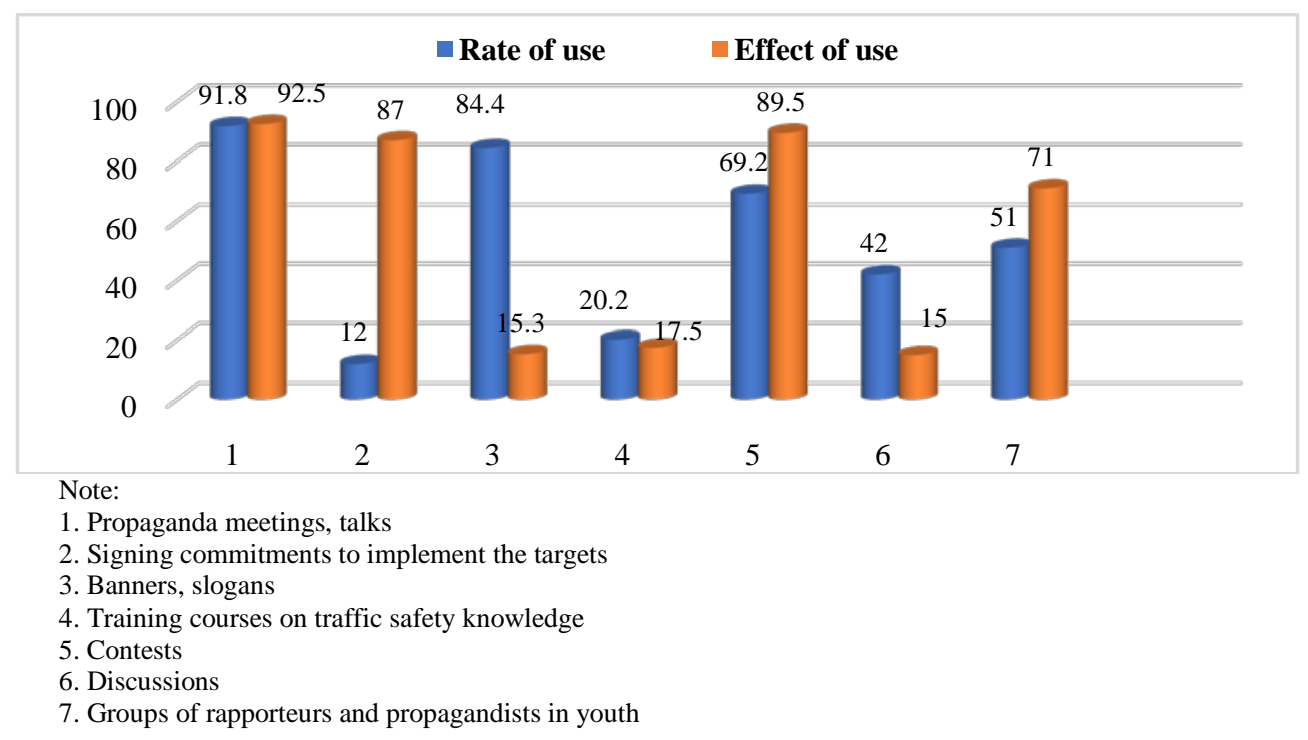

Chart 2. Comparison of the rate of use and the effectiveness of using traffic safety awareness measures for members of secondary schools in Tuy Hoa

Table 3. Advantages in educating the traffic safety awareness for members of high schools in Tuy Hoa City, Phu Yen Province

\begin{tabular}{|c|c|c|c|c|c|c|c|c|c|}
\hline \multirow{2}{*}{ Content } & \multicolumn{3}{|c|}{ Teachers $(\mathrm{N}=33)$} & \multicolumn{3}{|c|}{ Union members ( $\mathrm{N}=1000)$} & \multicolumn{3}{|c|}{ Total $(\mathrm{N}=1033)$} \\
\hline & Vol & Ratio & Rank & Vol & Ratio & Rank & Vol & Ratio & Rank \\
\hline 1. Getting the attention and support from the school board & 30 & 90.9 & 1 & 874 & 87.4 & 1 & 904 & 87.5 & 1 \\
\hline $\begin{array}{l}\text { 2. The coordination between departments and specialized boards in } \\
\text { the school }\end{array}$ & 21 & 63.6 & 4 & 658 & 65.8 & 4 & 679 & 65.7 & 4 \\
\hline $\begin{array}{l}\text { 3. The school board's delegation actively implemented the contents } \\
\text { of education on traffic safety awareness for members and youths }\end{array}$ & 25 & 75.8 & 2 & 743 & 7.3 & 3 & 768 & 74.3 & 3 \\
\hline 4. Responsibility of initial teams & 23 & 69.7 & 3 & 821 & 82.1 & 2 & 844 & 81.7 & 2 \\
\hline $\begin{array}{l}\text { 5. Close coordination between the Youth Union and the Ward } \\
\text { Police }\end{array}$ & 19 & 57.6 & 5 & 539 & 53.9 & 5 & 558 & 54 & 5 \\
\hline
\end{tabular}

* Advantages and disadvantages in the education of traffic safety awareness for members of high schools in Tuy Hoa.

- Advantages: The survey showed that the interest and support from the school board (teachers accounted for $90.9 \%$ of the surveyed members and $87,4 \%$ of union members) reached 87.5\%; The working and working efficiency of the initial teams is $81,7 \%$; Thirdly, the Executive Board of the Youth Union actively implemented the contents of education of traffic safety awareness for youth union members and youths, accounting for $74.3 \%$ (Table 3 ).

\section{- Difficulties:}

On the teachers' side, the first difficulty was that $81.8 \%$ of the members of the youth union were not well-behaved; At the same time, there is a lack of facility for the propaganda and education of traffic safety awareness among youth union members and youth, $75.7 \%$, and finally, materials for communication activities of the Youth Union of Traffic safety is limited to $72.7 \%$.

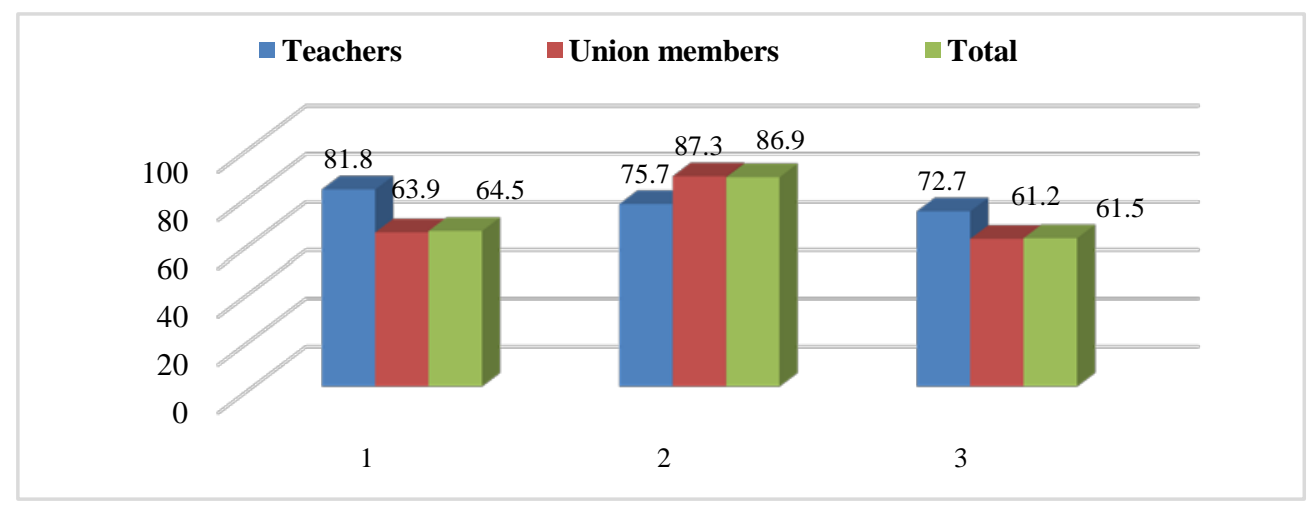

Note:

1. A part of unionists and young people are not well-behaved

2. Lack of facility to serve for the propaganda and education of the law enforcement traffic safety for union members

3. Limited information on traffic safety for the Youth Union

Chart 3. Difficulties in educating the law of traffic safety to students of secondary school in Tuy Hoa 
On the side of the union members: Lack of facility for propaganda and education of the law enforcement traffic safety for union members, youth $87.3 \%$, ranked first. Next came a part of unionists, young people have a sense of poor performance accounted for $63.9 \%$ and finally the document for communication activities of the Youth Union on traffic safety is limited to $61.2 \%$.

As such, most youth union members have basic knowledge about the Law on Road Traffic Safety which is propagated by schools as well as localities through various means and forms. The awareness of participation in strict compliance with traffic safety law in the youth union members has not been fully implemented, many union members still violate the law, ride in many rows... The traffic safety training for the students of secondary schools in Tuy Hoa is paid more attention daily with the regular organization level in the Youth Union and some local areas. The process of propagandizing and educating the traffic safety awareness for the members of secondary schools in Phu Yen has many advantages but also met a lot of difficulties. These difficulties are also challenges for managers.

\subsection{A Number of Community-based Educational Measures to Improve the Sense of Compliance with the Road Traffic Law for Students of Secondary Schools in Tuy Hoa City}

Based on the results of the study and the current situation of community-based education on the sense of compliance of road traffic law to students of secondary schools in Tuy Hoa, the authors propose 3 groups of measures with 9 specific measures as follows:

\subsubsection{Measure Group 1}

Raising the resources to ensure the education of the sense of compliance with the road traffic law to students of secondary schools in Tuy Hoa, Phu Yen province based on the community.

Measures 1. Improving the capacity and skills of communicators about traffic culture at schools and the community.

- Objectives, meaning: strengthening the role and responsibility of the communicators will encourage them to continuously improve their knowledge, cultivate the ability to propagate, innovate, innovate the model, educational activities.

- Content: Develop contents, programs and plans; Organize training courses to improve skills of communication; Organize seminars, conferences, rapporteurs and distributing documents for the activities of propagandists.

- Implementation: 1) Develop content, program, operation plan, annual, quarterly and monthly for communicators. Regularly organize training courses to improve the capacity and skills of communication culture promoters; 2) Organizing forums, seminars and workshops on topics related to traffic safety. To advise on the drafting and issuance of materials for traffic safety propagandists such as propaganda outlines, publications, books, banners, posters ...

- Conditions for implementation: high quality human resources; have enough personnel to propagate and educate students with different methods and have good qualifications in advising.

Measure 2. Enhancing the coordination of familyschool-community involvement

- Objective and meaning: The objective of the coordination is to unify the educational viewpoint, agree on the content and educational measures to help educate the sense of observance of the Law on Traffic The students achieved the highest results, avoiding the case of conflicts in understaning.

- Content: Raise the interest and educate the sense of observance of the Law on Transportation from the family, to unify the views, contents, measures and forms of education of the sense of observance of the Law on Traffic among Family-school-community.

- How to: Establish a close relationship between the family and the school and social organizations. In addition to the plan to organize traffic safety activities organized by the school, families need flexible solutions to educate and mobilize children to comply with traffic safety law. At the same time, the family must be the mirror always strictly observe the law for the children to follow.

- Conditions for implementation: The coordination between the family and the school must be compatible with the local economic and cultural development conditions, the level of awareness of each student's family, It is convenient for families, schools and communities to support each other, while developing appropriate regulations and regulations on conditions for coordination.

Measure 3. Mobilization of material facilities and equipment in service of propaganda and education

- Objectives and meanings: To prepare material foundations, resources and create an environment for propagation and education to build the sense of observance of the traffic safety law for unionists and high school students. High school in Tuy Hoa City was more favorable, since then, the propaganda and education is more effective.

- Content: To build solutions and regularly supplement equipment, tools, conditions on material foundations and warehouses for storing equipment and tools used efficiently and scientifically. . Mobilize the creativity of teachers and students to create tools to serve the propaganda and education activities more vivid and effective.

- How to do it: It is necessary to invest money to improve facility, to ensure sufficient equipment and tools for propaganda and education.

- Conditions for implementation: The school's management board must be familiar with the actual situation of deployment, feasibility and timely advising with relevant agencies.

\subsubsection{Measure Group 2}

Developing a traffic safety propaganda campaign in association with organizing the Youth Day with the Culture of Traffic and organizing contests on understanding of the Law on Road Traffic Safety

Measure 4. Developing a propaganda campaign on land roads

- Objectives and significance: To propagate the Party's and State's guidelines and policies on traffic safety through visual models to their members, pupils and people for a long time. 
- Content: Specifying the resolutions, directives, decrees, laws of the Party, the State ... on the task of ensuring traffic order and safety.

- Implementation: District-level delegations shall formulate and promulgate documents guiding and guiding the delegations, focusing on the delegations of upper secondary schools in the localities where construction of panels, boards of propaganda and safety Road traffic in crowded residential areas, traffic flowing with vivid images, suitable, easy to understand.

- Conditions for doing the job: staffs must be qualified, knowledgeable about traffic safety law, supported equipment for the construction of forms of communication on the internet ...

Measures 5. Developing a communication campaign on traffic safety through arts and cultural programs at schools and communities

- Objectives, meaning: Develop a campaign with solutions, scale, objectives and clear propaganda results through cultural and artistic activities at schools and localities. - Content: Establishing clubs, organizing festivals, traffic safety contests, song compositions, paintings, posters, propaganda posters, safety driving, traffic safety seminars

- Implementation: organizing communication activities on the propaganda channels of the delegation, social networking site ...

- Conditions for implementation: The campaign must be elaborated with concrete contents and solutions; have the force to implement and participate in ensuring the islands, practically.

Measures 6. Organizing the Youth Festival with Traffic Culture and the contest on road traffic safety law for union members of upper secondary schools in Tuy Hoa

- Objectives and meaning: To create a healthy and useful playground for union members and high school students to learn the Land Transport Law; promote the spirit of shock, volunteer union members, students in participating in propaganda activities to ensure traffic order and safety, thereby raising the sense and responsibility of each student obey the law about traffic safety.

- Content: Organizing a series of lively communication activities, such as propaganda, organizing traffic exchange forums, training safety driving skills and organizing knowledge contest of Traffic safety.

- How to do: organize parades, mittinh propaganda traffic safety... Regularly organize forums, seminars, seminars, performances, competitions, exchange programs of students about traffic safety and traffic safety training courses for the propagandists at the school, the volunteer and intial teams to ensure traffic safety...

- Implementation conditions: The organization's activities must be rich in content and diversified in form, practical and lively.

\subsubsection{Measure Group 3}

Promoting volunteer activities, intial teams to participate in ensuring traffic order and safety

Measure 7. Strengthening the activities of volunteer teams and initial youth teams to participate in ensuring traffic safety

- Objective, meaning: To promote the spirits of volunteers, union members and other students in joining hands with the community to ensure traffic safety in Tuy Hoa.

- Content: Improve the efficiency of volunteer and initial youth teams' activities at school gates and railway lines in residential areas. To bring into full play the strength of the initial teams participating in maintaining traffic order and safety and applying works and jobs to raising the sense of observance of traffic safety for students.

- Implementation: 1) Continue to maintain the model of "traffic safety school". Building a model of "crossroads safe railways" at the crossroads of people without barriers, spontaneous crossroads; 2) To set up teams and youth volunteer groups to guide and distribute traffic at traffic lights, traffic lights, support and assistance in case of traffic accidents.

- Conditions for implementation: Promote the spirit of the inital and volunteer teams to participate in ensuring the safety of traffic. However, the establishment of the teams should ensure some contents: permission, participation from the family and the school. The activities must be planned and guided in a detailed and consistent manner, in terms of content and action, to ensure safety and not to interfere with the student's learning.

Measure 8. Replicating models, works, tasks of union members to ensure traffic order and safety

- Objectives, meaning: Confirm and recognize the effectiveness of the model, and at the same time replicate models and works effectively in propagating traffic safety throughout the unit.

- Content: The Standing Committee of the Youth Union held a conference to summarize the results of traffic safety propaganda activities, through the conference to timely summarize, evaluate achievements, assess the shortcomings, reason; Appreciate the collective, individuals have achievements, models or solutions in Tuy Hoa in particular and Phu Yen province in general.

- Method of implementation: Annually, on the basis of results of activities at the Youth Union, the Youth Union organized a summation conference.

- Conditions for implementation: The model shall be summed up from the results of operation of the establishment, the reports sent by participants of the conference; comments of delegates; must hold a summation conference.

Measures 9. Educating union members in violating the administrative law on ensuring traffic order and safety.

- Objectives, meanings: To assist the youth union members in traffic safety violations to understand their violations, to see the possible consequences of traffic violations.

- Content: 1) Use many propaganda solutions to youth union members; 2) Attached to Youth Union activities to educate youth union members and youths who are aware of traffic safety as prescribed by law, specifically linked to the Cultural Festival organized by the Youth Union.

- How to do it: Organizing the competition, school radio activities on the cultural topics when participating in traffic of students. Regularly praise groups and individuals who have excellent achievements in propagating traffic safety for union members and students.

- Conditions for implementation: To elaborate propaganda plans with concrete, practical and thrifty contents. 
Actively coordinate with the authorities at all levels and mobilize members and students of the school actively participate in propaganda knowledge traffic safety.

\subsubsection{Relationship between Measures}

Between the above-mentioned measures, there is a unified, dialectical relationship with each other, inseparable from one another and simultaneously between the two measures, which are mutually binding and mutually supportive, together with the objectives and contents of the program of activities. To educate the road traffic safety awareness among members of high schools in Tuy Hoa city based on community in Phu Yen province.

Group 1 measures serve as a condition to improve the resources for the education of road traffic law enforcement: Fostering the capacity and skills of cultural propagandists School transportation, strengthening the coordination of family-school-community involvement as well as the mobilization of material facilities, equipment for grassroots dissemination and education, Strengthen the activities of organizing education propaganda awareness of compliance with road traffic law

Measures 2 set up traffic safety propaganda campaign in association with organizing youth festival as a "backbone" of propaganda and education. The construction of communication programs on traffic safety in the form of art and culture at schools and communities, organizing contests on the road traffic law for members of high schools Tuy Hoa city is the core campaign to introduce the road traffic law as well as the sense of responsibility to comply with road traffic safety law to individual members.

Group 3 measures to promote voluntary activities, young people to participate in ensuring traffic safety and order is considered as the core in the process of propagation, replication of the model of work, division of union members To participate in ensuring traffic order and safety; Educating union members in violating the administrative law on traffic order and safety protection are activities aimed at promoting and promoting further activities in order to raise the efficiency of the propagation and education of sense road safety of union members.

\subsubsection{To test the Urgency and Feasibility of the Proposed Measures}

We consulted 27 cadres, including 7 traffic police, 20 junior cadres at the grassroots level and the secretary of Tuy Hoa high school delegation through the questionnaire to find out about the suitability. , the necessity and feasibility of measures to educate road traffic safety awareness among union members in upper secondary schools in Tuy Hoa City, Phu Yen Province

c. Results of the assay on the urgency and feasibility of the proposed measures: the measures proposed by the author are highly effective as well as realistic and feasible.

- On the necessary level: Chart 4 shows that measures 2 -5-6-7 are considered to be quite high, accounting for 70.4 to $88.9 \%$ of the total surveyed population. The measures were rated as 1-8 and 9. The reason for these measures was less necessary because there were no personnel to attend regular training and retraining for the management team. Like the union members, high school students in Tuy Hoa, Phu Yen.

- About the level of feasibility

Chart 5 shows that all nine measures are highly valued by the participants. Some measures are underestimated to the requisite level, but the feasibility level is quite high, such as Measure 1 and Measure 9.

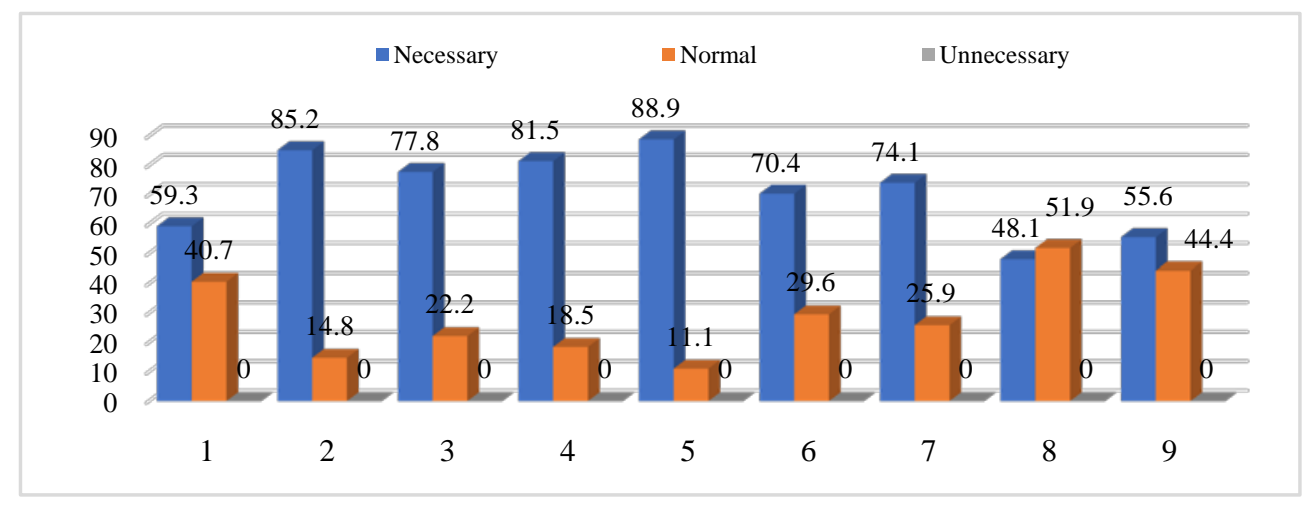

Chart 4. Necessity of the measures

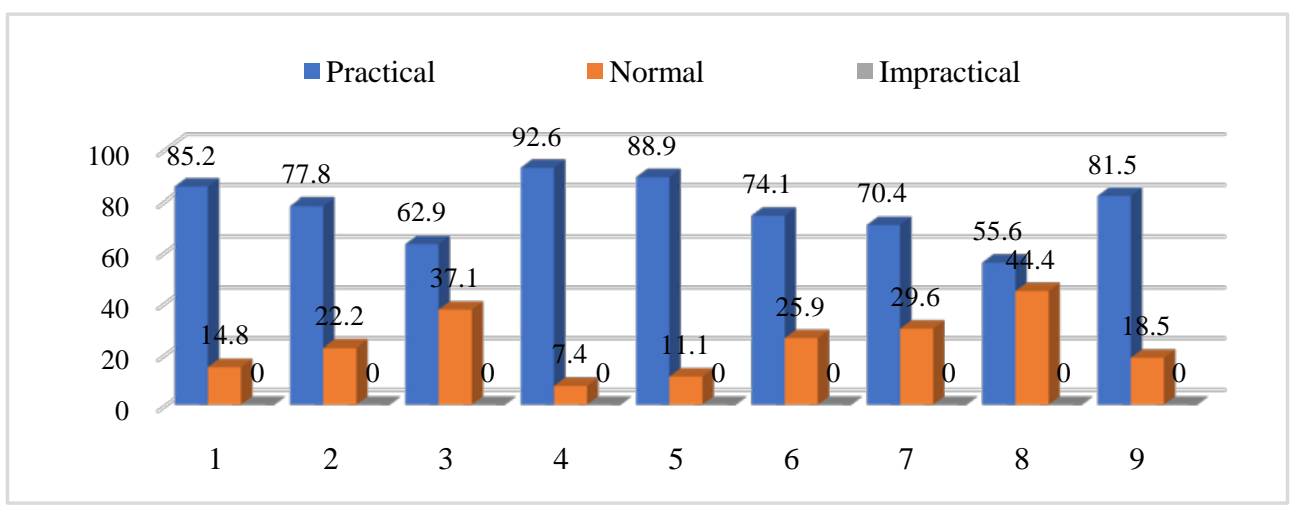

Chart 5. Practical degree of the measures 
Thus, the measures proposed by the authors are highly effective as well as realistic and feasible in the survey area.

\section{Conclusion}

Community-based education of the road traffic safety awareness to secondary school students in Tuy Hoa, Phu Yen province is a very important content for the community. Organization of dissemination activities, volunteer activities of the Youth Union organization greatly contributes to the education of raising the awareness of the members to increase the awareness of people in the community. The activities held by Youth unions help ensure the traffic order and safety in the province. Those activites tend to develop better in the future. The contents and methods of educating activites of road safety awareness to the students of secondary schools in Tuy Hoa, Phu Yen province have been experimented and proved appropriate and applicable to local situations. The results of the survey show that the road traffic safety education awareness to Union members of secondary schools in Tuy Hoa, Phu Yen province, have not many new, creative and effective activities. For better effects, it is necessary to carry out urgent and feasible measures in accordance with the conditions of Tuy Hoa, Phu Yen Province. The above measures are based on the principles of approach to meet the desire and appropriate characteristics of the living community.

\section{References}

[1] Federal (2012), Highway Administration. http://safety.fhwa.dot.gov/

[2] Alicea, L, Colucci, B, et. al., 2004, Analysis and Evaluation of Pedestrian Crashes in Urban Highways of Puerto Rico. Second LACCEI International Latin American and Caribbean Conference for Engineering and Technology

[3] Colucci B, et al. (2012), Programas Innovadores para Concientizar la Seguridad Vial en Puerto Rico. Revista Dimensión Ingeniería y Agrimensura CIAPR, yr. 26, 1.
[4] Colucci, B., Meléndez, I., Señeriz, S, (2013), Innovative Programs and Action Plan to Raise Road User Awareness in the Commonwealth of Puerto Rico Supporting the Decade of Action for Road Safety, Second Traffic Forum, 4-6 November 2013, Dammam, Saudi Arabia.

[5] Tamara Hoekstra, Fred Wegman, Improving the effectiveness of road safety campaigns: Current and new practices, IATSS Research, Volume 34, Issue 2, March 2011, Pages 80-86.

[6] Ainsworth, Highway Safety-Human Factors (2010), Education, and Enforcement Strategies, Louisiana Highway Safety Commission. [online] Available at: http://www.ltrc.lsu.edu/ltc.

[7] Wegman. F.C.M, Aarts. L.T. (Eds.) (2006), Advancing Sustainable Safety: National Road Safety Outlook for 2005-2020, SWOV Institute for Road Safety Research, Leidschendam (2006).

[8] Delhomme, P, De Dobbeleer, W, Forward. S, Simões A (Eds.) (2009) Manual for Designing, Implementing, and Evaluating Road Safety Communication Campaigns, Directorate-General for Energy and Transport, European Commission, Brussels.

[9] Chính phủ Việt Nam (2017), "Báo cáo kết quả thực hiện nhiệm vụ bảo đảm trật tự, an toàn giao thông năm 2017; phương hướng, nhiệm vụ bảo đảm trật tự an toàn giao thông năm 2018", Hà Nội (Government of Vietnam (2017), "Report on the performance of tasks of ensuring traffic order and safety in 2017; directions and tasks of ensuring traffic order and safety in 2018 ", Hanoi).

[10] Phương Hồng (2017),

http://www.baophuyen.com.vn/164/188497/de-ngan-chan-thanhthieu-nien-vi-pham-luat-giao-thong-duong-bo.html, trang điện tử: baophuyen.com.vn. (Phuong Hong (2017), http://www.baophuyen.com.vn, Website: baophuyen.com.vn)

[11] http://dantri.com.vn/giao-duc-khuyen-hoc/tang-cuong-hoat-donggiao-duc-an-toan-giao-thong-trong-truong-hoc20180321140945551.htm

[12] Ban an toàn giao thông (2017), “Báo cáo tổng kết công tác an toàn giao thông tỉnh Phú Yên năm 2017”, Tỉnh Phú Yên, Việt Nam. (Traffic Safety Board (2017), "Report on Traffic Safety in Phu Yen Province in 2017", Phu Yen Province, Vietnam.)

[13] Nguyễn Như Chiến (2008), "Nghiên cứu hành vi chấp hành Luật giao thông đường bộ của học sinh THCS khi tham gia giao thông”, Luận án tiến sĩ, Hà Nội. (Nguyen Nhu Chien (2008), "Study on traffic law abiding behavior of junior high school students in traffic", PhD thesis, Hanoi.)

[14] Ngô Xuân Thắng (2007), "Giao thông đường bộ Việt Nam thực trạng và giải pháp”, Diễn đàn Bộ giao thông vận tải, Việt Nam. (Ngo Xuan Thang (2007), "Road transport in Vietnam - current situation and solutions", Ministry of Transport, Vietnam.)

[15] Trần Sơn Hà (2016), "Quản lí nhà nước về trật tự, an toàn giao thông đường bộ ở Việt Nam hiện nay”, Luận án tiến sĩ, Hà Nội. (Tran Son Ha (2016), "State management of road traffic order and safety in Vietnam", PhD thesis, Hanoi.) 